\title{
Bankacılık Krizlerinin Belirleyicileri: Mikroekonometrik Bir Analiz
}

\section{Determinants of Banking Crisis: A Microeconometric Analysis}

Dilek ÇETİN $^{1}$, Gamze GÖÇMEN YAĞCILAR ${ }^{2}$

Article Info

Article History:

Date Submitted: 28.04.2019

Date Accepted: 20.05.2019

Jel Classification

C25, G18, G21

Keywords:

Banking,

Finance,

Crisis,

Logit
Abstract

Banking crisis is one of the obstacle for the economic stability. The smooth operation of the banking and finance markets should be taken into consideration carefully for both politicians and the foreign investors. The main aim of this study to analysis the main determinants of banking crisis. For this reason, World Bank's Global Financial Development database is used for to estimate single variable logit models. In this manner, it is tried to find the variables which accelerate the probability of banking crisis and the variables which decelerate it.

In sum, it is found that banking crisis is influenced by twenty seven variables positively and thirteen variables negatively. The variables which increases the probability of banking crisis are: bank cost to income ratio, bank credit to bank deposits, bank deposits to GDP, bank lending-deposit spread, bank noninterest income to total income, bank nonperforming loans to gross loans, bank overhead costs to total assets, central bank assets to GDP, deposit money banks' assets to GDP, domestic credit to private sector (\% of GDP), financial system deposits to GDP, GDP, GDP per capita, GNI, outstanding total international debt securities / GDP, life insurance premium volume to GDP, liquid liabilities in millions USD, liquid liabilities to GDP, nonbank financial institutions' assets to GDP, nonlife insurance premium volume to GDP, outstanding international private debt securities to GDP, outstanding international public debt securities to GDP, private credit by deposit money banks and other financial institutions to GDP, stock market total value traded to GDP, stock market turnover ratio, stock price volatility and, total factoring volume to GDP.

The variables which mitigate the probability of banking crisis are: 5-bank asset concentration, bank capital to total assets, bank concentration, bank net interest margin, bank return on assets (after tax), bank return on equity (after tax), bank Z-score, foreign bank assets among total bank assets, Lerner index, liquid assets to deposits and short term funding, number of listed companies per 1,000,000 people, remittance inflows to GDP and, stock market capitalization to GDP.

\footnotetext{
${ }^{1}$ Doç.Dr., Süleyman Demirel Üniversitesi, iïBF, İktisat Bölümü, dilekcetin@sdu.edu.tr, dilekchetin@gmail.com

${ }^{2}$ Dr. Öğr. Ü, Süleyman Demirel Üniversitesi, iïBF, Bankacılık ve Finans Bölümü, gamzeyagcilar@sdu.edu.tr
} 


\section{Özet}

Bankacılık krizleri, ekonomik istikrarın önündeki engellerden birisidir. Bankacılık ve finans piyasalarının düzgün bir şekilde işlemesi hem politikacılar hem de dış yatırımcılar açısından dikkatle ele alınması gereken bir husustur. Bu çalışmanın temel amacı bankacılık krizinin temel belirleyicilerini analiz etmektir. Bu amaçla Dünya Bankasının Küresel Finansal Gelişim veri tabanı kullanılarak, tek değişkenli lojistik modeli tahmin edilmiştir. Böylece, hangi değişkenlerin bankacılık krizi olasılığını arttırdığ1 ve hangi değişkenlerin bu olasılığ 1 azalttığ 1 bulunmaya çalışılmıştır.

Özet olarak, bankacılık krizlerinin yirmi yedi değişkenden pozitif ve on üç değişkenden ise negatif yönlü olarak etkilendiği bulunmuştur. Bankacılık krizlerinin olasılığını arttıran değişkenler: banka maliyeti gelir oranı, banka kredileri banka mevduatları oranı, banka mevduatları gayrisafi yurtiçi hasıla (GSYİH) oranı, banka borç verme ve mevduat faiz oranı farkı, banka faiz dışı gelirlerinin toplam gelirlere oranı, banka takipteki kredilerin brüt kredilere oranı, banka sabit maliyetlerinin toplam varlıklara oranı, merkez bankası varlıklarının GSYİH'ya oranı, mevduat bankalarının varlıklarının GSYİH'ya oranı, özel sektöre verilen yurtiçi krediler (GSYİH’nın \%’si), finansal sitem mevduatlarının GSYİH'ya oranı, GSYİH, kişi başına GSYİH, Gayrisafi Milli Gelir, ödenmemiş toplam uluslararası borçlanma tahvillerinin GSYİH'ya oran1, hayat sigortası prim hacminin GSYİH'ya oran1, likit yükümlülükler, likit borçların GSYİH’ya oranı, bankalar dışı finansal kurumların varlıklarının GSYİH'ya oranı, hayat-dışı sigorta primlerinin GSYİH'ya oranı, ödenmemiş uluslararası özel borçlanma senetlerinin GSYİH'ya oranı, ödenmemiş uluslararası kamu borçlanma senetlerinin GSYİH'ya oranı, mevduat bankaları ve diğer finansal kurumların özel kredilerinin GSYİH'ya oranı, hisse senedi piyasasında toplam işlem hacminin GSYİH'ya oranı, borsa devir hızı oranı, hisse senedi fiyatlarının oynaklığı ve toplam faktöring hacminin GSYİH'ya oranıdır. Bankacılık krizlerinin olasılığını azaltan değişkenler: 5-banka varlığı yoğunlaşması, banka sermayesinin toplam varlıklara oranı, banka yoğunlaşması, bankanın net faiz marjini, varlıklar üzerinden banka getirisi (vergi sonrası), özsermaye üzerinden banka getirisi (vergi sonras1), banka Z-puanı, yabancı banka varlıklarının toplam banka varlıkları içindeki payı, Lerner endeksi, likit varlıkların mevduat ve kısa vadeli fonlara oranı, 1 milyon kişi başına listelenen firma sayısı, havale akışının GSYİH'ya oranı ve borsa kapitalizasyonun GSYİH’ya oranıdır. 


\section{Giriş}

1980 'den itibaren tüm dünyada ekonomik ve finansal krizlerin yanı sıra bankacılık krizleri de ciddi şekilde ekonomik sistemi tehdit eder hale gelmiştir. Ekonomik istikrarının bir göstergesi de bankacılık ve finans sisteminin istikrarlı olmasından geçmektedir. Bunun için politika yapıcılar genellikle bir krizle karşılaştıktan sonra piyasalara müdahale ederek istikrarı sağlamaya çalışırlar. İktisatçılar ve finansçıların amaçlarından biri de matematiksel, istatistiksel ya da ekonometrik yöntem kullanarak ekonomi, finans ya da bankacıllk krizlerini önceden tahmin etmeye çalışmaktır.

Ekonomide, finans piyasasında ve bankacılık sektöründe birçok değişken eşanlı olarak birbirlerinden etkilendiklerinden dolayı krizleri temel olarak etkileyen faktörlerin saptanması önem kazanmaktadır. Literatürde bütün iktisatçıların kabul ettiği bankacılık krizlerini tanımlayan genel bir model bulunmamaktadır. Bu çalışmada amaç geniş bir veri seti kullanarak dünya çapında bankacılık krizlerinin belirleyicilerinin neler olduğunu saptamaktır. Bunların belirlenmesi bu çalışmadan sonra yapılacak olan çalışmalarda bankacılık krizlerini modellemede seçilecek değişkenleri belirleme olanağı tanırken ikinci olarak değişkenlerin etkilerinin kıyaslamasını da mümkün kılacaktır. Bu çalışmanın bundan sonra yapılacak çalışmalara yol gösterici olması planlanmaktadır.

\section{Literatür Taraması}

Demirgüç-Kunt ve Detragiache (1997) bankacılık krizi olasılığını hesaplamak için çok değişkenli lojistik model kullanmışlardır. Çalışma 1980-1994 dönemini kapsamaktadır. Bulgular şu şekildedir: Düşük GSYİH büyüme oranı, bankacılık krizi olasılığını arttırmaktadır. Ticaret haddindeki düşüş de bankaların dayanıklılığını olumsuz etkilemektedir. Reel faiz oranı ve enflasyon yüksek anlamlılık derecesine sahip değişkenlerdir ve ikisi de kriz olasılığını arttırmaktadır. M2/rezervler de anlamlıdır ve kriz olasılığını arttırmaktadır. Mevduat sigortası uygulaması bankalarda ahlaki tehlike (moral hazard) problemi yaratarak kriz olasıllı̆ııı arttırmaktadir.

Demirgüç-Kunt ve Detragiache (1998) 1980-95 dönemini ve IMF üyesi 53 ülkeyi inceledikleri çalışmalarında finansal serbestleşmenin finansal kırılganlık üzerindeki etkilerini incelemişlerdir. $\mathrm{Bu}$ amaçla çok değişkenli lojistik model uygulanmıştır. Bulgular finansal serbestleşmenin bankacılık krizi olma olasılığını arttırdığ1 fakat kurumsal çevrenin güçlü olduğu ülkelerde bu ihtimalin zayıfladığı yönündedir. Özellikle hukukun üstünlüğü, düşük 
yolsuzluk oranları ve sözleşme hükümlerine uyum gibi unsurlar kurumsal karakteristiklerle ilişkilidir. Finansal olarak bastırılmış ülkelerin, bankacılık krizi deneyimlemiş olsalar dahi serbestleşme sonrası finansal ilerlemeler yaşadıkları da görülmüştür.

Hardy ve Pazarbaşığlu (1999), bankacılık sistemlerinde meydana gelen sıkıntı ve krizler üzerinde hangi makroekonomik ve finansal değişkenlerin öncü göstergeler olabileceğini incelemişlerdir. Elde edilen bulgular bankacılıkta yaşanan sıkıntılara reel GSYİH'da eşzamanlı düşüşlerin, enflasyonda, kredi genişlemesinde ve sermaye girişlerinde ani yükseliş ve düşüş döngülerinin, reel faiz oranlarında yükseliş ve marjinal sermaye çıktısı rasyosunda düşüşlerin, reel kurlarda keskin düşüşlerin ve ters ticaret şoklarının eşlik ettiği yönündedir.

1970-1995 dönemi için 20 ülkeyi kapsayan bir örneklem üzerinden hareketle Kaminsky ve Reinhart (1999), 26 bankacılık ve 76 döviz krizini incelemişlerdir. Kaminsky ve Reinhart (1999), 16 gösterge için belirlenen eşik değerlerin, ödemeler dengesi ve bankacılık krizleri için öncü göstergeler olabileceğini öne sürmüşlerdir. Eşik değerlerinin aşılması sinyal kabul edilen göstergeler şunlardır: Finansal sektör: M2 çarpanı, yurt içi krediler/GSYİH, M1 dengesinin fazlalığ kuru, ithalat, rezervler, reel faiz oranı farkları, reel sektör üretim, stok fiyatları, bütçe açıkları/GSYİH. Çalışmada ayrıca finansal serbestleşme sonrası bankacılık krizleri ve döviz krizleri yakın bağlantılı bulunmuştur.

1980-1997 dönemini ve 69 ülkeyi kapsayan çalışmalarında Beck vd. (2006), lojistik model uygulayarak bir ülkenin bankacılık krizi yaşama olasılığı üzerinde ulusal banka yoğunlaşmasının, bankacılık düzenlemelerinin ve ulusal kurumların etkilerine dair ülkeler arası bir değerlendirme sağlamışlardır. Sistemik bankacılık krizi, ulusal bankaların takipteki kredilerinin toplam aktiflere oranının \%10'u aşması ya da sıra dışı hükümet müdahaleleri (örneğin bir bankanın tatil edilmesi veya bankacılık sisteminin önemli bir bölümünün kamulaştırması gibi) şeklinde kendini göstermektedir. Elde edilen bulgular, yoğunlaşmanın yüksek olduğu sektörlerde sistemik bankacılık krizi gerçekleşme olasılığının düşük olduğunu ortaya koymaktadır.

Leaven ve Valencia (2008), 1970-2007 döneminde gerçekleşen 42 kriz vakası üzerinde çalışmışlardır. Çalışmada yazarlar sistematik bankacılık krizini şöyle tanımlamaktadırlar: Sistematik bir bankacılık krizinde, ülkenin işletmeleri ve finansal sektörü çok sayıda iflas deneyimler ve finansal kurumlar ve işletmeler borçlarını zamanında ödemekte zorluklar yaşarlar. Sonuç olarak takipteki krediler hızlı bir şekilde artar ve bankacılık sektörünün toplam 
sermayesi tükenir. Bu duruma varlık fiyatlarının düşmesi, reel faizlerdeki artışlar ve sermaye akımlarının azalması ya da tersine dönmesi de eşlik edebilir. Bazı durumlarda kriz mevduat sahiplerinin bankalara hücum etmesini tetikleyebilir. Yazarlar banka hücumlarını ise banka mevduatında aylık \%5'i aşan düşüşler şeklinde tanımlamaktadırlar.

Boyd vd. (2009), 1980-2002 dönemi için 91 ülkeyi kapsayan çalışmalarında, daha yoğunlaşmış bankacılık sektörlerinin sistematik bankacılık şokları ile karşılaşma olasılığının daha yüksek olduğunu bulmuşlardır. Mevduat sigortası uygulaması ve finansal açıklık, sistemik bankacılık şokları üzerinde anlamlı bir etki yaratmamaktadır. Buna karşılık daha esnek kur düzenlemeleri sistemik bankacılık şoku olasılığını azaltmakta, döviz krizlerinin ardından ise bankacılık şoklarının yaşanma olasılığı artmaktadır.

Angkinand vd. (2010), 1973-2005 yılları arasında 48 ülkede yaşanan finansal reformların bankacılık krizleri ile ilişskisini ele almışlardır. Buna göre bankacılık krizleri ile finansal serbestleşme arasında ters $U$ şeklinde bir ilişki olduğu sonucuna varılmıştır. Yani belirli bir seviyeye kadar finansal serbestleşme bankacılık krizlerinin gerçekleşme olasılığını arttırsa da bu seviyeden sonra artan serbestleşme kriz olasılığını azaltmaktadır. Bankacılık krizlerinin çoğunlukla orta seviyede bir finansal serbestleşmenin akabinde meydana geldiği görülmüştür. Ayrıca serbestleşme ve bankacılık krizleri arasındaki ilişkinin sermaye düzenlemelerinin ve denetimin gücüne sıkı sıkıya bağlı olduğu bulunmuştur. Bankacılık krizlerini en çok etkileyen serbestleşme türü ise davranışsal olanlarıdır (faiz ve kredi kontrollerinin esnetilmesi).

Barrell vd. (2010), 1980'den itibaren ülkelerin cari açıklarının OECD ülkelerinde bankacılık krizlerinin gerçekleşme olasılığı üzerindeki etkisini incelemişlerdir. Multinominal lojistik modeli kullanılarak bankacılık krizinin gerçekleşme olasılığı hesaplanmıştır. Cari açık/GSYİH (negatif), reel konut fiyatları büyümesi (pozitif), ağırlıklandırılmamış banka sermaye yeterliliği (negatif) ve bankaların dar likidite/varlıklar oranı (negatif) anlamlı bulunan değişkenlerdir. Krediler/GSYİH oranının, kriz riskinden ziyade OECD ülkeleri için finansal sistemin doğasını yansıttığ düşünülmektedir.

Babecky vd. (2012)'nin AB ve OECD üyesi 40 gelişmiş ülkenin 1970-2010 yılları arasındaki çeyrek dönem verilerini kapsayan çalışmalarında bankacılık, borç ve döviz krizleri incelenmiştir. 30 makroekonomik ve finansal göstergenin krizleri açıklama gücü belirlenmeye çalışılmış ve erken uyarı sinyalleri tespit edilmeye çalışılmıştır. Elde edilen sonuçlar gelişmiş ülkelerdeki bankacılık krizlerinin erken uyarı göstergesi olarak en tutarlı değişkenin Yurtiçi özel krediler/GSYİH oranı olduğunu ortaya koymaktadır. Ayrıca, doğrudan yabancı sermaye 
yatırımlarının artması, para piyasası faizlerinin yükselmesi ve küresel ekonomik patlamalar (dünya GSYİH ve enflasyonunun yükselmesi) da gözlenmesi gereken faktörler olduğu belirtilmiştir.

Antunes vd. (2014), gelecek bankacılık krizini tahmin etmenin neredeyse olanaksız olduğunu iddia etmişlerdir. Bununla birlikte yazarlara göre hisse senedi fiyat endeksi, kredi/GSYİH açı̆̆ı, borç/hizmetler rasyosu, konut fiyatları endeksi, gelişen krizlerin sinyali olarak kullanılabilecek göstergelerdir. Özellikle kredi/GSYİH açığı ve borç/hizmetler oranının büyümesi, en güçlü ve en tutarlı sonuçları veren değişkenler olarak bulunmuştur. Ayrıca konut fiyatlarındaki güçlü yükselişleri takip eden keskin inişlerin yaşandığı dönemler, sistematik bankacılık krizlerinin yaşanma olasılığının yüksek olabileceği dönemler olarak yorumlanmıştır.

Jutasompakorn vd. (2014), 1995-2010 yılları arasında yaşanan bankacılık krizlerinin tanımlanmasına ve belirleyicilerinin anlaşılmasına odaklanmışlardır. Çalışmanın sonucunda LIBOR-OIS oranı bankacılık krizlerinin yeni bir belirleyicisi olarak bulunmuştur. Bu oran, para piyasalarındaki sıkıntının bir göstergesi olarak son yıllarda yakından izlenmektedir. Bu sonuç, artan finansal entegrasyonun, fonlar üzerindeki likidite baskısını sistemik iflas meselesine dönüştürebileceğine işaret etmektedir.

Boyd vd. (2015), 1970-2011 döneminde 85 ülkenin yaşadığı bankacılık şokları üzerinde çalışmışlardır. Kontrol değişkenleri reel GSYİH büyümesi, enflasyon ve kredi /GSYİH büyümesi olup, çalışmanın asıl amacı, mevduat sigortası uygulamasının sistemik bankacılık şoklarının gerçekleşme olasılığını nasıl etkilediğini araştırmaktır. Bulgulara göre, mevduat sigortası uygulaması, sistemik bir bankacılık krizi olasılığını arttırmamakta fakat beklendiği gibi politik tepkilerin artmasına yol açmaktadır.

Laina vd. (2015), 11 AB ülkesinde 1980-2013 döneminde yaşanan bankacılık krizleri incelemişlerdir. Kredi/mevduat oranı ile konut fiyatları büyümesinin en iyi öncü göstergeler olduğu bulunmuştur. Kriz, ülke düzeyinde bankacılık sektörünün yaşadığı sistematik stres olarak ifade edilmiştir. Sistematik bankacılık krizleri, bir bütün olarak bankacılık sisteminin sermayesinin zayıflatan eşanlı başarısızlıkların ortaya çıktığı ve çoğunlukla bir hükümet müdahalesini gerektiren durumlar olarak tanımlanmıştır.

Wosser (2015), 1998-2011 dönemi için gelişmiş ve gelişmekte olan 75 ülkeyi kapsayan bir çalışma yapmıştır. Lojistik modelin çözümüyle elde edilen sonuçlara göre, Tier-1 sermayesi üç yıl boyunca anlamlı bir artış sergilediğinde, sistematik bir bankacılık krizinin gerçekleşme olasılığının azaldığı görülmüştür. Diğer taraftan Tier-1 sermayenin düzeyi, kriz olasılığ1 
üzerinde anlamlı bulunmamıştır. Çalışmanın diğer bulguları şu şekildedir: Net istikrarlı fonlama oranı gibi bir likidite rasyosunun tanıtılması daha dayanıklı bir bankacılık sistemine katkı yapmamaktadır. Aynı şekilde, düzenleyici yapının yalnızca küçük bir kısmı sektörel istikrar ile ilişkilidir. Ticari faaliyetlerin kısıtlanması, giriş gerekliliklerin arttırılması gibi düzenlemeler daha güvenli bankalarla sonuçlanırken, diğer düzenleyici standartlar, örneğin uygulanacak sermaye yeterliliği kuralları, bankaların sistematik riske maruz kalma derecelerini azaltmamaktadır. Ayrıca, yoğunlaşmış bankacılık sektörünün daha istikrarlı olduğuna dair bir kanit elde edilememiştir.

Ar1 ve Cergibozan (2016), 1990-2003 dönemini kapsayan çok değişkenli lojistik model kullanmışlardır. Bankacılık krizlerini temsilen, finansal kırılganlık endeksi oluşturulmuştur. Bunun için bankaların takipteki krediler/toplam krediler oranındaki değişim, bankaların karı/bankaların özkaynakları oranındaki değişim ve yabancı para mevduatın toplam mevduata oranındaki değişim hesaplanarak, her biri kendi standart sapmasına bölünmek suretiyle ağırlıklandırılmış ve toplanmıştır. Elde edilen sonuçlara göre bankacılık krizleri üzerinde anlamlı bir etkiye sahip olan değişkenler, aşırı para arzı ve bankaların kısa pozisyonudur (açık pozisyon-yani yabancı para yükümlülükler yabancı para alacaklardan fazla). Ayrıca bir dönem önceki döviz krizinin de bankacılık krizlerinin kilit etkenlerinden olduğu ifade edilmiştir.

Hamdaoui (2016), gelişmiş ve gelişmekte olan 49 ülke ve 1980-2010 yılları arasını kapsayan çalışmasında bankacılık sistemini zayıflatan ve krizin çıkmasına neden olan faktörleri tanımlamayı amaçlamıştır. Öncü göstergelerin belirlenmesinde multinominal lojistik modelin öngörü gücünü arttıran Bayesci Model Ortalama (Bayesian Model Averaging - BMA) yöntemi kullanılmıştır. Reel efektif döviz kurunun normal trendinden sapması ve reel faiz oranındaki hızlı yükselişler, ticaret haddi ve sermaye akımları ile bankacılık sisteminin yabancı piyasalara açıklığı kriz olasılığını yükselten değişkenler olarak bulunmuştur. Diğer yandan yüksek cari işlemler fazlası, yüksek finansal bağlantı ve yüksek kişi başına GSYİH, iyi işleyen bankacılık sisteminin bulunduğu ekonomileri ifade ettikleri için kriz olasılığını azaltan değişkenlerdir.

Koepke (2016), 27 gelişen ekonomide yaşanan krizler üzerinde ABD'de uygulanan para politikalarının etkilerini araştırmıştır. 1973-2014 arasında yaşanan döviz, bankacılık ve borç krizlerinin belirleyicilerinin analiz edildiği çalışmada negatif binom sayım modeli ile panel lojistik modeli kullanılmıştır. Sonuçlar şu durumlarda kriz olasılığının daha yüksek olduğunu göstermektedir: i. Federal fonların faizi normal düzeyinin üzerine çıktığında, ii. FED’in 
sıkılaştırma uyguladığı dönemlerde ve iii. Piyasa katılımcıları FED’in önceden beklenenden daha hızlı bir sıkılaştırma uygulayacağına ilişkin beklenmedik işaretler aldıklarında.

Lang ve Schmidt (2016), dünya ekonomisinin \%95'ini oluşturan 70 ülkeyi ve son küresel mali krizi de içeren 1975-2010 dönemini kapsayan çalışmalarında aylık veri seti kullanmışlardır. Elde edilen bulgular yurtiçi kredilerin, banka yatırım yükümlülükleri/GSYİH oranının, kamu harcamaları/gelirleri oranının kriz olasılığını arttıran, geniş likidite rasyosu, vadesiz mevduat ve reel menkul kıymet fiyatlarının ise olasılığı azaltan anlamlı değişkenler olduğunu ortaya koymaktadır. Varlık fiyatlarının da bankacılık problemleri için önemli bir erken uyarı göstergesi olduğu tespit edilmiştir.

Pena (2016) 1961-2012 dönemi ve tamamı AB ve OECD üyesi 36 ülkeyi ele alarak, gelir dağılımındaki bozukluğun bankacılık krizi riski üzerinde pozitif ve anlamlı bir etkisi olduğu sonucuna varmıştır. Gelir dağılımındaki bozukluğun krize geçişinin bütçe açıkları kanalı ile olduğu tespit edilmiştir. Ayrıca gelişmiş ülkelere coğrafi olarak uzak olmak da finansal sıkıntı riskini azaltmaktadır.

Cergibozan ve Arı (2017), Markow rejim değişim modeli uygulayarak 1990-2013 döneminde Türkiye'de yaşanan ekonomik krizlerin nedenleri araştırmışlardır. Enflasyon ve faiz oranlarının artması, TL'nin değer kaybetmesi, banka kredilerinin artması, likidite problemi, kamu bütçe dengesinin bozulması, banka rezervlerinin azalması ve banka açı pozisyonunun artması Türkiye'de bankacılık krizlerinin temel belirleyicileri olarak bulunmuştur. Bankaların merkez bankasından yüksek oranda kredi kullanması krizlerle pozitif, sermaye yeterlilik oranı ise negatif ilişkili değişkenler arasında sayılmıştır.

Gluzman ve Guzman (2017), 1973-2005 döneminde yaşanan bankacılık krizlerinin farklı türden finansal reformlarla arasındaki ilişkiyi değerlendirdikleri çalışmalarında sermaye hesaplarındaki, menkul kıymet piyasalarındaki ve faiz oranlarındaki serbestleşmenin, kredi kontrolleri ile giriş bariyerlerinin kaldırılmasının ve bankacılık sektöründe kamu payının azaltılmasının bankacılık krizlerinin frekansının yükselmesiyle ilişkili olduğunu göstermişlerdir. Diğer taraftan, reform sonrası finansal türbülansın beş yıllık bir zaman penceresinde yoğunlaştığı; bu süre zarfinda kriz yaşanmamışsa, sonrasında yaşanma olasılığının daha düşük olduğu anlaşılmıştır.

Antunes vd. (2018), 1970-2012 dönemi için 22 Avrupa ülkesini ele almışlar ve menkul kıymet fiyatları, konut fiyatları artışı, krediler/GSYİH ve borç servisi oranının gelişen krizlere dair önemli sinyaller olduğunu tespit etmişlerdir. 
Pedro vd. (2018), 1991-2011 dönemi OECD ülkelerini ele aldıkları çalışmalarında bankaların nispeten küçük, borç düzeylerinin yüksek olduğu ülkelerde, ekonominin hız kestiği ve yüksek enflasyon oranlarının kaydedildiği durumlarda bankacılık krizlerinin daha fazla görüldüğünü ortaya koymuşlardır. Ülkeler arasında bulaşma etkisinin olduğu tespit edilmiştir. Bu etki özellikle birbirine coğrafi olarak yakın ülkeler arasında ve G7 ülkeleri arasında görülmüştür. Bankacılık faaliyetleri üzerindeki düzenleme ve denetimlerin ise bankacılık krizlerini önlemede başarısız olduğu sonucuna varılmıştır. Banka temelli finansal sistemlerin bankacılık krizi yaşama olasılıkları daha düşük bulunmuştur ve piyasa temelli ülkeler için borç daha önemli bir sıkıntı kaynağı olarak görülmüştür.

\section{Yöntem ve Analiz Sonuçları}

Bankacılık krizlerinin sebeplerini belirlemek için literatürde kullanılan temel yöntem lojistik ya da multinominal lojistik regresyondur. Bu çalışmada tek değişkenli lojistik yöntemi kullanarak çalışmanın hipotezi test edilecektir. Çalışmada Dünya Bankası'nın (World Bank) Küresel Finansal Gelişim veri tabanı (Global Financial Development Database ${ }^{3}$ ) kullanılacaktır. Bu bölümde kısaca yöntem, veri seti ve çalışmanın bulguları hakkında bilgi verilecektir.

\subsection{Yöntem}

Literatürde çok değişkenli lojistik (Demirgüç-Kunt ve Detragiache, 1997; Demirgüç-Kunt ve Detragiache, 1998) ya da multinominal lojistik regresyon (Barrell vd., 2010; Hamdaoui, 2016) yöntemi kullanılmıştır. Bu çalışmada temel analiz yöntemi olarak tek değişkenli lojistik ile her bir bağımsız değişkenin bankacılık krizlerine etkisi analiz edilmeye çalışılmıştır. Bu sonraki çalışmalarda bankacılık krizleriyle ilgili modellerin kullanılmasında seçilecek bağımsız değişkenler için bir yol gösterecektir.

Bağımlı değişken olan bankacılık krizinin iki koşul birlikte gerçekleştiğinde ortaya çıktığı düşünülmektedir. Bunlardan birincisi finansal sıkıntı için kayda değer işaretlerin (önemli bankaya hücum (bank run), bankacılık sisteminde ve/veya banka likitlerinde kayılar) olmasıdır. İkincisi ise bankacılık sistemindeki ciddi kayıplar karşısında kayda değer bankacılık politika müdahalesinin alınmasıdır. İki koşulun sağlandığı ilk yıl, krizin sistemik olmaya başladığ̣ yıl olarak düşünülmektedir. Hem reel GSYİH büyümesinin hem de reel kredi büyümesinin pozitif olduğu en az iki ardışık yıldan önceki yılda krizin bitiş yılı olarak

\footnotetext{
${ }^{3}$ Daha detaylı bilgi için https://www.worldbank.org/en/publication/gfdr/data/global-financial-developmentdatabase (Erişim tarihi: 15.04.2018)
} 
tanımlanmaktadır (Leaven ve Valencia, 2013). Bankacılık krizleri iki terimli değişken olarak tanımlanmıştır yani krizin olduğu yıllarda 1, diğer yıllarda 0 değeri alan iki terimli bir değişkendir.

Lojistik regresyonun standart regresyondan farkı, bağımlı değişkenin ikili değişken (0-1) olmasıdır. Katsayılarının standart regresyondaki gibi yorumlanabilmesi içinde marjinal etkilerin hesaplanması gerekmektedir (daha detaylı bilgi için Cameron ve Trivedi, 2005; Long ve Freese, 2006)

\subsection{Veri}

Bu çalışmada Dünya Bankasının (World Bank) Küresel Finansal Gelişim veri tabanı (Global Financial Development Database ${ }^{4}$ ) kullanılmıştır. 1964-2013 yılları arasında 203 ülkenin finansal sistem özelliklerini içeren 10,153 veri bulunmaktadır. Bu veri tabanında dört ana başlıkta veri bulunmaktadır (Cihak vd., 2012):

i. $\quad$ Finansal derinlik (financial depth) (finansal kurum ve piyasaların büyüklüğü),

ii. Finansal piyasalara erişim (access) (bireylerin finansal hizmetleri kullanma ve kullanabilme oran1),

iii. Finansal etkinlik (efficiency) (aracı kaynakların kullanımında ve finansal işlemleri kolaylaştırmada finansal aracıların ve piyasaların etkinliği),

iv. Finansal istikrar (stability) (Finansal kurumların ve piyasaların istikrarı).

Veri setindeki 117 farklı değişken bulunmaktadır. Bütün verileri içeren bir özet istatistik tablosu çok yer kaplayacağından dolayı Ek-1'de sadece bankacılık krizlerini pozitif etkileyen 27 değişkene, Ek-2 de ise negatif etkileyen 13 değişkene ait özet istatistik tablosu verilmiştir.

\subsection{Analiz Sonuçları}

Veri tabanında bulunan 117 değişken ile tek değişkenli lojistik tahmin edilmiştir. İstatistiksel olarak asimptotik özellikleri sağlaması açısından sadece bin gözlemin üzerindeki regresyon sonuçları tablolanmıştır. Sonrasında ise her bir regresyon için marjinal etkiler hesaplanmıştır. Sonuçlar iki grupta toplanmıştır. Tablo 1'de pozitif etkileyen değişkenler yani bankacılık krizlerinin olasılığını arttıran değişkenler, Tablo 2'de ise bu olasılığı azaltan yani negatif etkileyen değişkenler gösterilmiştir.

\footnotetext{
${ }^{4}$ Daha detaylı bilgi için https://www.worldbank.org/en/publication/gfdr/data/global-financial-developmentdatabase (Erişim tarihi: 15.04.2018)
} 


\section{ANALIZ SONUÇLARI}

Tablo 1: Bankacılık krizlerinin olasılığını arttıran değişkenler (Marjinal etkiler) (Bağımlı değişken bankacılık krizleri)

\begin{tabular}{|c|c|c|c|c|c|c|}
\hline & Değişken & Variable & Katsay & Olasılik & $\begin{array}{l}\text { Gözlem } \\
\text { Sayısı }\end{array}$ & $\begin{array}{l}\text { Grup } \\
\text { Say1s1 }\end{array}$ \\
\hline 1 & Banka maliyeti gelir oranı (\%) & $\begin{array}{l}\text { Bank cost to income ratio } \\
(\%)\end{array}$ & 0.0297 & 0.000 & 2447 & 190 \\
\hline 2 & $\begin{array}{l}\text { Banka kredileri banka } \\
\text { mevduatları oranı }(\%)\end{array}$ & $\begin{array}{l}\text { Bank credit to bank } \\
\text { deposits }(\%)\end{array}$ & 0.0023 & 0.023 & 6946 & 184 \\
\hline 3 & $\begin{array}{l}\text { Banka mevduatları GSYİH } \\
\text { oranı }(\%)\end{array}$ & Bank deposits to GDP (\%) & 0.0232 & 0.000 & 5899 & 180 \\
\hline 4 & $\begin{array}{l}\text { Banka borç verme ve mevduat } \\
\text { faiz oranı farkı }\end{array}$ & $\begin{array}{l}\text { Bank lending-deposit } \\
\text { spread }\end{array}$ & 0.0364 & 0.000 & 3810 & 169 \\
\hline 5 & $\begin{array}{l}\text { Banka faiz dış1 gelirlerinin } \\
\text { toplam gelirlere oranı }\end{array}$ & $\begin{array}{l}\text { Bank noninterest income } \\
\text { to total income }(\%)\end{array}$ & 0.0205 & 0.003 & 2443 & 190 \\
\hline 6 & $\begin{array}{l}\text { Banka takipteki kredilerin brüt } \\
\text { kredilere oranı }(\%)\end{array}$ & $\begin{array}{l}\text { Bank nonperforming loans } \\
\text { to gross loans }(\%)\end{array}$ & 0.1874 & 0.000 & 1331 & 126 \\
\hline 7 & $\begin{array}{l}\text { Banka sabit maliyetlerinin } \\
\text { toplam varlıklara oranı }(\%)\end{array}$ & $\begin{array}{l}\text { Bank overhead costs to } \\
\text { total assets }(\%)\end{array}$ & 0.0716 & 0.016 & 2265 & 190 \\
\hline 8 & $\begin{array}{l}\text { Merkez Bankası varlıklarının } \\
\text { GSYİH'ya oranı }(\%)\end{array}$ & $\begin{array}{l}\text { Central bank assets to } \\
\text { GDP }(\%)\end{array}$ & 0.0204 & 0.000 & 5492 & 177 \\
\hline 9 & $\begin{array}{l}\text { Mevduat bankalarının } \\
\text { varlıklarının GSYIH'ya oranı } \\
(\%)\end{array}$ & $\begin{array}{l}\text { Deposit money banks' } \\
\text { assets to GDP }(\%)\end{array}$ & 0.0249 & 0.000 & 5882 & 180 \\
\hline 10 & $\begin{array}{l}\text { Özel sektöre verilen yurtiçi } \\
\text { krediler (GSYİH’nın \%'si) }\end{array}$ & $\begin{array}{l}\text { Domestic credit to private } \\
\text { sector }(\% \text { of GDP) }\end{array}$ & 0.0256 & 0.000 & 6681 & 183 \\
\hline 11 & $\begin{array}{l}\text { Finansal sitem mevduatlarının } \\
\text { GSYİH'ya oranı }(\%)\end{array}$ & $\begin{array}{l}\text { Financial system deposits } \\
\text { to GDP }(\%)\end{array}$ & 0.0214 & 0.000 & 5895 & 180 \\
\hline 12 & GSYİH (cari US\$) (logaritma) & $\begin{array}{l}\text { GDP (current US\$) } \\
(\text { logarithm) }\end{array}$ & 0.3826 & 0.000 & 7693 & 200 \\
\hline 13 & $\begin{array}{l}\text { Kişi başına GSYİH (US\$) } \\
\text { (logaritma) }\end{array}$ & $\begin{array}{l}\text { GDP per capita (constant } \\
2005 \text { US\$) } \\
\text { (logarithm) }\end{array}$ & 0.0463 & 0.000 & 7403 & 196 \\
\hline 14 & $\begin{array}{l}\text { Gayrisafi Milli Gelir (US\$) } \\
\text { (logaritma) }\end{array}$ & $\begin{array}{l}\text { GNI (current US\$) } \\
\text { (logarithm) }\end{array}$ & 0.3798 & 0.000 & 7368 & 198 \\
\hline 15 & $\begin{array}{l}\text { Ödenmemiş toplam uluslararası } \\
\text { borçlanma tahvillerinin } \\
\text { GSYİH'ya oranı }(\%)\end{array}$ & $\begin{array}{l}\text { Outstanding total } \\
\text { international debt } \\
\text { securities / GDP }(\%) \\
\end{array}$ & 0.0763 & 0.000 & 1447 & 99 \\
\hline 16 & $\begin{array}{l}\text { Hayat sigortası prim hacminin } \\
\text { GSYİH'ya oranı }(\%)\end{array}$ & $\begin{array}{l}\text { Life insurance premium } \\
\text { volume to GDP }(\%)\end{array}$ & 0.1893 & 0.002 & 2740 & 163 \\
\hline 17 & $\begin{array}{l}\text { Likit yükümlülükler (milyon \$) } \\
\text { (2000 sabit fiyatlarla) } \\
\text { (logaritma) }\end{array}$ & $\begin{array}{l}\text { Liquid liabilities in } \\
\text { millions USD }(2000 \\
\text { constant) }\end{array}$ & 0.2566 & 0.000 & 6917 & 183 \\
\hline 18 & $\begin{array}{l}\text { Likit borçların GSYİH'ya oranı } \\
(\%)\end{array}$ & $\begin{array}{l}\text { Liquid liabilities to GDP } \\
(\%)\end{array}$ & 0.0258 & 0.000 & 5883 & 180 \\
\hline 19 & $\begin{array}{l}\text { Bankalar dışı finansal } \\
\text { kurumların varlıklarının } \\
\text { GSYİH'ya oranı }(\%)\end{array}$ & $\begin{array}{l}\text { Nonbank financial } \\
\text { institutions' assets to GDP } \\
(\%)\end{array}$ & 0.0077 & 0.006 & 1586 & 70 \\
\hline 20 & $\begin{array}{l}\text { Hayat-dışı sigorta primlerinin } \\
\text { GSYİH'ya oranı }(\%)\end{array}$ & $\begin{array}{l}\text { Nonlife insurance } \\
\text { premium volume to GDP } \\
(\%)\end{array}$ & 0.3438 & 0.000 & 2996 & 166 \\
\hline 21 & $\begin{array}{l}\text { Ödenmemiş uluslararası özel } \\
\text { borçlanma senetlerinin } \\
\text { GSYİH'ya oranı }(\%)\end{array}$ & $\begin{array}{l}\text { Outstanding international } \\
\text { private debt securities to } \\
\text { GDP }(\%)\end{array}$ & 0.0667 & 0.000 & 1222 & 88 \\
\hline
\end{tabular}




\begin{tabular}{|c|c|c|c|c|c|c|}
\hline 22 & $\begin{array}{l}\text { Ödenmemiş uluslararası kamu } \\
\text { borçlanma senetlerinin } \\
\text { GSYIH'ya oranı }(\%)\end{array}$ & $\begin{array}{l}\text { Outstanding international } \\
\text { public debt securities to } \\
\text { GDP }(\%)\end{array}$ & 0.0557 & 0.000 & 1325 & 96 \\
\hline 23 & $\begin{array}{l}\text { Mevduat bankaları ve diğer } \\
\text { finansal kurumları özel } \\
\text { kredilerinin GSYİH'ya oranı } \\
(\%)\end{array}$ & $\begin{array}{l}\text { Private credit by deposit } \\
\text { money banks and other } \\
\text { financial institutions to } \\
\text { GDP }(\%)\end{array}$ & 0.0293 & 0.000 & 5905 & 181 \\
\hline 24 & $\begin{array}{l}\text { Hisse senedi piyasasında } \\
\text { toplam işlem hacminin } \\
\text { GSYIH'ya oranı (\%) }\end{array}$ & $\begin{array}{l}\text { Stock market total value } \\
\text { traded to GDP }(\%)\end{array}$ & 0.0040 & 0.017 & 1977 & 112 \\
\hline 25 & Borsa devir hızı oranı $(\%)$ & $\begin{array}{l}\text { Stock market turnover } \\
\text { ratio }(\%)\end{array}$ & 0.0047 & 0.002 & 1978 & 112 \\
\hline 26 & $\begin{array}{l}\text { Hisse senedi fiyatlarının } \\
\text { oynaklığ }\end{array}$ & Stock price volatility & 0.0459 & 0.000 & 1423 & 83 \\
\hline 27 & $\begin{array}{l}\text { Toplam faktöring hacminin } \\
\text { GSYİH'ya oranı }\end{array}$ & $\begin{array}{l}\text { Total factoring volume to } \\
\text { GDP }(\%)\end{array}$ & 0.1967 & 0.000 & 1026 & 76 \\
\hline
\end{tabular}

Tablo 2: Bankacılık krizlerinin olasılığını azaltan değişkenler (Marjinal etkiler) (Bağımlı değişken bankacılık krizleri)

\begin{tabular}{|c|c|c|c|c|c|c|}
\hline & Değişken & Variable & Katsay 1 & Olasilik & $\begin{array}{l}\text { Gözlem } \\
\text { Sayıs }\end{array}$ & $\begin{array}{l}\text { Grup } \\
\text { Sayis1 }\end{array}$ \\
\hline 1 & 5-banka varlığı yoğunlaşmas1 & 5-bank asset concentration & -0.0215 & 0.005 & 1667 & 153 \\
\hline 2 & $\begin{array}{l}\text { Banka sermayesinin toplam } \\
\text { varlıklara oran } 1 \%)\end{array}$ & $\begin{array}{l}\text { Bank capital to total assets } \\
(\%)\end{array}$ & -0.1232 & 0.004 & 1312 & 124 \\
\hline 3 & Banka yoğunlaşması (\%) & Bank concentration (\%) & -0.0131 & 0.043 & 2043 & 169 \\
\hline 4 & Bankanın net faiz marjini (\%) & $\begin{array}{l}\text { Bank net interest margin } \\
(\%)\end{array}$ & -0.2947 & 0.000 & 2250 & 189 \\
\hline 5 & $\begin{array}{l}\text { Varlıklar üzerinden banka } \\
\text { getirisi (vergi sonrası, \%) }\end{array}$ & $\begin{array}{l}\text { Bank return on assets (\%, } \\
\text { after tax) }\end{array}$ & -0.4606 & 0.000 & 2266 & 190 \\
\hline 6 & $\begin{array}{l}\text { Özsermaye üzerinden banka } \\
\text { getirisi (vergi sonrası, \%) }\end{array}$ & $\begin{array}{l}\text { Bank return on equity (\%, } \\
\text { after tax) }\end{array}$ & -0.0982 & 0.000 & 2263 & 190 \\
\hline 7 & Banka Z-puanı & Bank Z-score & -0.0318 & 0.040 & 2254 & 185 \\
\hline 8 & $\begin{array}{l}\text { Yabancı banka varlıklarının } \\
\text { toplam banka varlıkları } \\
\text { içindeki payı }(\%)\end{array}$ & $\begin{array}{l}\text { Foreign bank assets among } \\
\text { total bank assets }(\%)\end{array}$ & -0.0205 & 0.001 & 2312 & 128 \\
\hline 9 & Lerner endeksi & Lerner index & -4.2971 & 0.000 & 2058 & 138 \\
\hline 10 & $\begin{array}{l}\text { Likit varlıkların mevduat ve } \\
\text { kısa vadeli fonlara oranı }(\%)\end{array}$ & $\begin{array}{l}\text { Liquid assets to deposits } \\
\text { and short term funding (\%) }\end{array}$ & -0.0196 & 0.003 & 2479 & 191 \\
\hline 11 & $\begin{array}{l}1 \text { milyon kişi başına listelenen } \\
\text { firma sayısı }\end{array}$ & $\begin{array}{l}\text { Number of listed } \\
\text { companies per } 1,000,000 \\
\text { people }\end{array}$ & -0.0080 & 0.018 & 2286 & 120 \\
\hline 12 & $\begin{array}{l}\text { Havale akışının GSYİH'ya } \\
\text { oranı (\%) }\end{array}$ & $\begin{array}{l}\text { Remittance inflows to } \\
\text { GDP }(\%)\end{array}$ & -0.0964 & 0.000 & 4617 & 184 \\
\hline 13 & $\begin{array}{l}\text { Borsa kapitalizasyonun } \\
\text { GSYİH'ya oranı (\%) }\end{array}$ & $\begin{array}{l}\text { Stock market capitalization } \\
\text { to GDP }(\%)\end{array}$ & -0.0073 & 0.005 & 2004 & 114 \\
\hline
\end{tabular}

\section{Bulguların Yorumlanması}

Analizden elde edilen bulgular 5 başlık altında toplanarak yorumlanabilir. Buna göre karlılık, aracılık, riskler, rekabet, finansal sistem ve konjoktür ile ilişkili değişkenlerin kriz olasılığ üzerindeki etkileri alt başl1klardaki gibidir. 


\subsection{Karlılık}

Bankalarda maliyetlerin artışı, beklendiği üzere krizlerin gerçekleşme olasılığını arttırmaktadır. Yüksek maliyetler bankaların karlarını düşürmekte ve muhtemel şoklara karşı bankaları daha kırılgan hale getirmektedir. Sabit maliyetlerin toplam varlıklara oranı da bankanın bir işletme olarak yüksek kaldıraçla çalıştığını gösterir. Buna göre gelirlerin azaldığı dönemlerde bankaların üzerinde sabit maliyetlerden kaynaklanan çeşitli yükler söz konusu olmakta, bankanın riski yükselmektedir.

Net faiz marjı, faiz gelirleri ile faiz giderleri arasındaki farkın bankanın toplam aktiflerine bölünmesiyle elde edilir ve bankaların önemli bir karlılık göstergesidir. Bankaların esas faaliyetlerinden elde ettiği gelir olup bankaların etkin bir aracılık faaliyeti yürüttüğüne ve finansal performansına işaret etmektedir. Bankalar, mevduat şeklinde topladıkları fonları kredi olarak kullandıran ve ideal olarak karlarının önemli bir bölümünü kredi-mevduat faiz farkından sağlayan finansal kurumlardır. Dolayısıyla bu farkın yüksek olmasının bankaların karlarına olumlu bir katkı yaparak sağlamlıklarını desteklemesi beklenmektedir. Dolayısıyla negatif katsayı alması, yani kriz olasılığı ile negatif ilişkili bulunması beklenen bir sonuçtur. Diğer taraftan faiz dışı gelirlerin toplam gelirlere oranı kriz olasılığı ile pozitif ilişkili bulunmuştur. Her iki sonuç birbiriyle tutarlıdır. Çünkü faiz dışı gelirler her ne kadar faiz gelirlerinin düşük olduğu dönemlerde bankaların toplam karını destekleyen bir gelir unsuru olsa da bu tür gelirlerin artması bankanın esas faaliyet konusundan uzaklaştığı şeklinde anlaşılabilir.

Bankaların aktif karlılıkları ve özsermaye karlılıkları da beklendiği gibi kriz olasılığını azaltan değişkenlerdir. Bu bulgu, karlılığı yüksek bir bankacılık sektörünün finansal şoklara karşı daha dayanıklı olduğu şeklinde yorumlanabilir. Kriz olasılığını düşüren diğer bir değişken, banka sermayesinin toplam varlıklara oranıdır. Sermaye, borç verenlere karşı bir güvence ve olası zararlara karşı bir tampon işlevi görür. Dolayısıyla sermaye yapısı güçlü olan bir banka hem daha geniş finansman olanaklarına sahip olacak hem de sıkıntılı dönemlerde mevduat çekilmesine daha az maruz kalacaktır. Sektörel olarak ele alındığında da yüksek sermaye oranıyla faaliyet gösteren bir sektörde kriz yaşanma olasılığı daha düşük olacaktır. Bu sonuç Cergibozan ve Arı (2017)'nın bulguları ile uyumludur.

\subsection{Aracilık}

Kredilerin mevduata oranına bakıldığında ortaya çıkan pozitif etki ise artan kredi talebini finanse etmek noktasında tasarrufların yetersiz kaldığı ve bankaların kredi verirken diğer borçlanma imkanlarına başvurduğu şeklinde anlaşılabilir. Kredileri finanse etmek için bankalar 
daha fazla borçlandığında ise riskleri artmakta ve finansal sıkıntı içerisinde girme olasılıkları yükselmektedir. Buna ilave olarak tasarrufların üzerinde artan bir kredi genişlemesi piyasada para talebinin arttığına işaret etmektedir. Bu talep üretime ve neticesinde satışa ve gelire yönelmediği sürece genel ekonomide risklerin artmasına yol açacaktır. Nitekim Laina vd (2015: 20)'ne göre kredi/mevduat oranı bankacılık krizlerinin en başarılı iki öncü göstergesinden biridir. Ayrıca Cergibozan ve Arı (2017), bankaların kredi arzını arttırmalarının ilerleyen dönemlerde sorunlu kredilerin artmasına yol açarak kriz olasılığını yükselteceğini öne sürmüşlerdir.

Bankaların kredi-mevduat faiz oranları arasındaki oransal fark, kriz olasılığı ile pozitif ilişkili bulunan diğer bir değişkendir. Bu değişkenin kriz olasılığıyla pozitif ilişkili bulunması, söz konusu farkın bireysel riskler nedeniyle yüksek tutulan kredi faizlerinden kaynaklanabileceğini akla getirmektedir. Özellikle kredi talebinin yüksek olduğu dönemlerde bankalar kredi faizlerini daha da arttırma eğilimde olabilirler. Yüksek faizli ancak riskli krediler bankaların kırılganlığını, buna bağlı olarak da kriz olasılığını arttırmaktadır. Kaminsky ve Reinhard (1999) bankacılık krizlerinin yaşandığı dönemlerde kredi faizleri ile mevduat faizleri arasındaki farkın açıldığını, bunun sebebinin de kriz dönemlerinde bankaların borç vermekten kaçınmaları olduğunu belirtmişlerdir. Özel sektöre verilen yurtiçi kredilerin GSYİH'ya oranı ile birlikte düşünüldüğünde her iki değişkenin de aldığı pozitif katsayı kriz dönemlerinde meydana gelen kredi genişlemesine dair literatürde öne sürülen iddialarla uyumludur (Kaminsky ve Reinhart (1999), Antunes vd. (2014), Babecky vd. (2012), Cergibozan ve Arı (2017), Lang ve Schmidt (2016)).

Toplam mevduatın GSYİH'ya oranı ülkede tasarruf hacminin arttığını göstermektedir. Aynı zamanda bankacılık sistemine duyulan güvenin de bir göstergesidir. Kriz olasılığını arttırması, beklenen bir sonuç değildir. Nitekim Kaminsky ve Reinhart (1999) ile Hardy ve Pazarbaşığlu (1999), mevduatta yaşanan kayıpların, banka hücumlarının göstergesi olabileceğini ifade etmektedirler ve mevduatın krizlerle negatif ilişkisini ortaya koymaktadırlar. Beklenenin aksine bu değişkenin kriz olasılığını arttırması, yüksek mevduatla birlikte bankaların artan yükümlülüklerinin bir sonucu olabilir. Bu değişkenin daha iyi yorumlanması için vadeye göre ve mevduat sahiplerine göre ayrıştırmalar yapılması yerinde olacaktır. Örneğin Han ve Melecky (2013: 4) mevduatın daha geniş kesimler tarafından sağlanmasının, kriz dönemlerindeki mevduat çekilmelerini ve banka hücumlarını yumuşattığını, aynı zamanda düşük gelir düzeyindeki tasarruf sahiplerinin farklı konjonktür dönemlerinde de finansal davranışlarını 
sürdürdüğünü belirtmişlerdir. Buna göre düşük gelir gruplarının mevduatları bankalar için kriz dönemlerinde dahi sürekli bir kaynak niteliği taşımaktadır.

Finansal sistem mevduatlarının GSYİH'ye oranı da krizlerle pozitif ilişskili bulunmuştur. Bu bulgu hem Toplam Mevduat/GSYİH değişkeniyle hem de Han ve Melecky (2013)'ün yukarıda ifade edilen değerlendirmeleri ile tutarlıdır.

Özel sektöre açılan kredilerin GSYİH’ya oranı da kriz olasılığını arttıran bir değişkendir. Babecky vd. (2012: 3) bu değişkenin uzun vadeli trendini \%2'den fazla aşmasının, bankacılık krizlerine dair bir erken uyarı göstergesi olarak görülebileceğini öne sürmüştür. Lang ve Schmidt (2016) da bu oranın krizler yaklaşırken normalin üstüne çıktığını bulmuştur. Elde edilen bulgu bu çalışmalar ile uyumludur.

\subsection{Riskler}

Takipteki kredilerin toplam kredilere oranının yüksek olması bir taraftan bireysel olarak banka açısından gelir kaybı olurken, sektörel bir artış genel ekonomide yaşanan problemlerin de habercisi olabilmektedir. Dolayısıyla geri dönmeyen kredilerle başlayan süreç, finansal sıkıntı problemlerini ve ardından sistematik krizleri tetikleyebilmektedir. Arı ve Cergibozan (2016), takipteki kredi oranını finansal kırılganlığın bir unsuru olarak ele almıştır. Demirgüç-Kunt ve Detragiache (1997), Beck vd. (2006), Leaven ve Valencia (2008) takipteki kredi oranlarının eşik değerlere ulaşmasının yaşanmakta olan bir bankacılık krizinin göstergelerinden olduğunu belirtmişlerdir.

Likit yükümlülüklerin tutarı ve likit yükümlülüklerin GSYİH'ya oranı birer risk faktörü olarak karşımıza çıkmaktadır. Bunlar bankaların kısa süre içerisinde ödemek zorunda oldukları borçlarıdır. Vadesiz ve 1 aya kadar vadeli mevduatlar bu yükümlülükler arasında yer alır. Bu değişkenin yüksekliği bankanın likidite riskinin yüksekliği ile ilişkilidir. Kriz olasılığını pozitif etkileyen en yüksek katsayılı değişkenlerden biri likit yükümlülüklerin tutarıdır.

Likit varlıkların mevduat ve diğer kısa vadeli fonlara oranı, bankaların likidite riskine açıklığını gösteren bir değişkendir. Bankacılık sektörünün finansal şoklar karşısında kırılganlığını arttıran faktörlerin başında, doğası gereği uzun vadeli yatırımların (örneğin kredileri) nispeten kısa vadeli kaynaklarla (örneğin mevduat) finanse edilmesi gelmektedir. Bu da bankaların kısa vadeli yükümlülüklerini yerine getirmede sorun yaşama olasılıklarını arttırmaktadır. Kısa vadeli ve nakde hızlı çevrilebilen plasman olanakları daha fazla olan bir bankacılık sektöründe sistemik bir kriz yaşanma olasılığ 1 da daha az olacaktır. Analizden elde edilen bulgular da bu yöndedir. Ancak bu sonuç Wosser (2015) ve Pena (2016)'nın bulguları ile ters yöndedir. 
Z-skoru, bireysel olarak bir bankanın iflas riskinden ne kadar uzakta olduğunu gösterir. Dolayısıyla bu değişkenin aldığı yüksek değerler bankalar açısından sağlamlık göstergesidir. Bankacılık krizleri ile ilişkisi beklendiği gibi negatiftir.

Gerek hayat sigortası gerekse hayat dışı sigorta primlerinin hacminin GSYİH'ye oranı kriz olasılığını pozitif etkilemektedir ve katsayıları da oldukça yüksektir. Bu değişkenlerin yükssek değer alması, bireysel risklerin yükseldiğine işaret edebilir. Çünkü hem sigorta primlerinin yükselmesinden hem de sigortalanmak isteyenlerin sayısının artmasından kaynaklanabilir. Bireysel risklerin arttığı anlamına gelebilecek bu değişkenlerin yüksek değer alması neticesinde bankalarda kredilerin geri dönüşü zora girebilir ve bankaların finansal sıkıntı yaşamasına yol açabilir.

Ekonomide ülke dışından temin edilen kaynakları temsilen üç değişken kullanılmıştır. Bunlar, henüz ödenmemiş uluslararası özel, kamusal ve toplam borçlanma araçlarının GSYİH'ya oranıdır ve üç değişkenin de krizlerle ilişkisi pozitiftir. Ülke dışından gerçekleştirilen borçlanmaların hacmi arttıkça finansal riskler artmakta ve ekonomi döviz riskine de daha açık hale gelmektedir.

\subsection{Rekabet}

Yoğunlaşma ile bankacılık sektörünün istikrarı arasındaki ilişkiye dair literatürde ortak bir kanaat bulunmamaktadır. Beck vd. (2006)'nin bulguları yoğunlaşmanın kriz olasılığını düşürdüğünü ortaya koymaktadır. Wosser (2015) bu görüşü destekleyen bir kanıt elde edememiştir. Boyd vd. (2009) ise yoğunlaşmış sektörlerin sistemik şoklarla karşılaşma olasılığının daha yüksek olduğunu öne sürmüşlerdir. Bu çalışmadan elde edilen sonuçlar ise yoğunlaşma göstergelerinin kriz olasılığını azalttığı yönündedir. Yoğunlaşma-istikrar hipotezini destekleyen bu sonuç yoğunlaşmış bankacılık sektörlerinde daha az rekabetçi fiyatlama davranışlarının bankaların karlılığını arttırarak kırılganlığı azalttığı görüşü ile uyumludur.

Sektörel rekabet yapısının ölçüsü olan Lerner Endeksi de yüksek katsayıya sahip bir değişken olarak karşımıza çıkmaktadır. Lerner endeksi “ 0 ” ile "1" arasında değerler almaktadır. Rekabet arttıkça endeksin değeri “0”'a, azaldıkça "1"e yaklaşmaktadır. Analizden elde edilen negatif katsayı, rekabetin azalması ile sistemik bankacılık krizlerinin görülme olasılığının da azaldığı şeklinde yorumlanabilir. Yoğunlaşma ve rekabet arasında ters yönlü bir ilişki olduğu düşünülürse bu değişken için elde edilen sonuç yoğunlaşma göstergeleri ile de uyumludur. Analiz sonuçlarına göre yoğunlaşma arttıkça ve rekabet azaldıkça bankacılık sektörü daha 
istikrarlı bir yapıya kavuşmaktadır. Pena (2016) banka krizlerinin belirleyicilerini araştırdığ 1 çalışmasında Lerner endeksini modeline dahil etmiş ve bizim bulgularımızla paralel biçimde negatif katsayı elde etmiştir.

Yabancı banka varlıklarının toplam banka varlıkları içerisindeki payı, kriz olasılığını düşüren diğer bir değişkendir. Yabancı bankaların sektörün istikrarını arttırıcı bir etkisi olduğu söylenebilir. Yurtdışı yatırım ve finansman olanaklarının fazlalı̆̆ı yabancı bankaların ulusal şoklardan daha az etkilenmelerini sağlayarak, bir bankada meydana gelen sıkıntının sektörün geneline yayılma derecesini düşürebilir.

\subsection{Finansal sistem ve konjonktür}

Krizler üzerinde en yüksek etkiye sahip değişkenler arasında GSYİH ve GSMH göze çarpmaktadır. Literatürde çoğunlukla GSYİH reel artışı kontrol değişkeni olarak modele dahil edilmektedir (örneğin Demirgüç-Kunt ve Detragiache (1998), Beck vd. (2006), Angkinand vd. (2010), Koepke (2016), Lang ve Schmidt (2016), Hamdaoui (2016), Gluzman ve Guzman (2017)) ve kriz olasılığ GSMH hacmine ait pozitif katsayılar, ekonomik faaliyetlerin artması paralelinde yaşanmış olabilecek kredi genişlemesinin, bankalar için ilave riskler yaratmasından kaynaklanmış olabilir. Benzer bir durum kişi başına GSYİH değeri için de söz konusudur. Hamdaoui (2016), yüksek kişi başına GSYİH'nın iyi işleyen bir ekonomiye işaret ettiği ve bu nedenle de kriz olasılığını azalttığı sonucuna varmıştır. Ancak bizim analizlerimizden bu değişkene ilişkin elde edilen katsay1 pozitiftir.

Borsa kapitalizasyonu gelişmiş bir finansal sisteme işaret etmektedir ve krizlerle ilişskisi beklendiği gibi negatiftir. Borsaya kote olan firma sayısının 1 milyon kişiye bölünmesiyle elde edilen oran, firmaların finansman sağlamada sermaye piyasalarından ne derece faydalandığını temsil eden, sermaye piyasalarının gelişmişliğine dair alternatif bir değişkendir. Kriz olasılığını düşürdüğü görülmektedir.

Hisse senedi getirilerinin volatilitesi, genel ekonomide ve finansal piyasalarda yaşanan risklerin yüksekliğine işaret eder. Aynı zamanda yatırımcıların piyasalara ilişkin güveninin zayıfladığını ve tedirginliğin arttığını gösterir. Bankacılık krizleri ile ilişkisi pozitif yönlüdür. Piyasalarda volatilitenin yükselmesi beklendiği gibi kriz olasılığını arttırmaktadır. Borsada işlem hacminin ve menkul kıymetlerin likiditesi ifade eden "turnover (devir hızı)" oranının artması da kriz olasılı̆̆ını arttıran unsurlar olarak karşımıza çıkmıştır. İşlem hacmi ve likidite borsada aranan 
özellikler olmasına rağmen kriz dönemlerinde borsadaki çöküşleri ve yurt içindeki paranın dışarıya kaçmasını hızlandırabilir. Bu da analizden elde edilen pozitif ilişkiyi açıklayabilir. Faktöring hacminin GSYİH'ya oranı da bankacılık krizleri ile pozitif ilişkili bulunmuştur. Bu sonuç iki şekilde yorumlanabilir: i) Faktöring işlemlerinin artması işletmelerin nakit sıkıntısı içerisinde olmasından kaynaklanıyorsa, akabinde bankaların geri dönmeyen kredilerinin artması da muhtemeldir. Bu durum sistemik bir krize yol açabilir. ii) Nakit sıkıntısı içerisinde olmayıp, işletmeler yalnızca nakit akışlarını düzene sokmak için faktöring hizmeti alıyorsa, bankalar üzerinde faktöring şirketlerine karşı bir rekabet baskısı oluşabilir. Artan rekabet bankaların karlarını olumsuz etkileyebilir ya da bankaları ters seçim (adverse selection) problemi ile karşı karşıya bırakabilir. Benzer bir yorum banka dışı finansal kurumların varlıklarının GSYİH'ya oranı için de yapılabilir. Elde edilen pozitif katsayı, banka dışı finansal kurumların rekabeti nedeniyle bankaları krize sürükleyen gelişmelerin meydana gelebileceği anlamına gelebilir.

Kriz olasılığını azaltan diğer bir değişken ise yurtdışından gelen havalelerin GSYİH'ya oranıdır. Diğer ülkelerde çalışan yurttaşların kendi ülkelerine gönderdikleri paralar, ödemeler bilançosundaki açıkların telafi edilmesinde de önemli katkılar sağlamaktadır. Dolayısıyla krizlerle ilişkisi, beklendiği gibi negatif bulunmuştur.

Merkez Bankası varlıklarının GSYİH’ya oranı kriz olasılığını arttırmaktadır. Özellikle iç varlıkları arttıran faktörler arasında Merkez Bankasının Hazine’ye ya da diğer bankalara açtığı krediler ve satın aldığı devlet borçlanma araçları sayılabilir. Bu da parasal genişleme yoluyla enflasyona zemin hazırlayabilir. Dolayısıyla bu değişken krizlerle pozitif ilişkili bulunmuştur. Mevduat bankalarının varlıklarının GSYİH'ya oranı da bir yandan bankacılık sisteminin gelişmişliğini gösterirken, diğer yandan ekonominin ne oranda bankacılık sistemine dayandığını ortaya koyabilmektedir. Lang ve Schmidt (2016), krizlerin başlamasından bir süre önce bu oranda anlamlı bir artış meydana geldiğini göstermiştir. Analiz sonuçları da bu çalışmayı destekler nitelikte olup, değişkenin katsayısı pozitiftir.

\section{Sonuç}

Bankacılık krizleri özellikle 1980'lerden itibaren ekonomik istikrarı tehdit eden önemli unsurlardan biridir. Bankacılık krizlerinin önceden belirlenerek, krizleri etkileyen değişkenlerdeki değişim dikkatlice incelenerek krizlere karşı önlem alınarak istikrar ortamı daha rahat sağlanabilir. Bankacılık krizlerini tahmin edebilmek için öncelikle bu krizleri 
etkileyen ya da olasılığı arttıran değişkenlerin belirlenmesi gerekmektedir. Bu çalışmadaki temel amacımız bankacılık krizinin belirleyicilerinin belirlenmesidir. Bunun içinde Dünya Bankasının Küresel Finansal Gelişim veri tabanı kullanılmıştır. Tek değişkenli lojistik modeli ile her bir değişkenin bankacılık krizini olasılığına etkisi tahmin edilmiştir. Böylece, hangi değişkenlerin bankacılık krizi olasılığını arttırdığ1 ve hangi değişkenlerin bu olasılığ1 azalttığ1 bulunmaya çalışılmıştır.

Özet olarak, bankacılık krizlerinin olasılığını yirmi yedi değişkenin arttırdığı ve on üç değişkenin ise azalttığı bulunmuştur. Analizden elde edilen bulgular beş başlık (karlılık, aracılık, riskler, rekabet, finansal sistem ve konjoktür) altında toplanarak yorumlanmıştır. Analiz sonuçları genel olarak literatürle uyumludur. Literatürden farklı olarak hem ülke bazında hem de değişken bazında geniş kapsamlı bir analiz yapılmıştır. Bundan sonraki aşamada bütün değişkenler kullanılarak bankacılık krizi tahmin modeli geliştirilmesi umulmaktadır. 


\section{KAYNAKÇA}

Angkinand, A. P., Sawangngoenyuang, W., \& Wihlborg, C. (2010), Financial Liberalization and Banking Crises: A Cross-Country Analysis. International Review of Finance, 10, 263-292.

Antunes, A., Bonfirm, D., Monteiro, N., \& Rodrigues, P.M.M. (2014), Early Warning Indicators of Banking Crises: Exploring New Data and Tools, Banco De Portugal, Economic Bulletin, 90-103.

Antunes, A., Bonfirm, D., Monteiro, N., \& Rodrigues, P.M.M., (2018), Forecasting Banking Crises with Dynamic Panel Probit Models, International Journal of Forecasting, 34, 249-275.

Ar1, A., \& Cergibozan, E. (2016), The Twin Crises: Determinants of Banking and Currency Crises in the Turkish Economy, Emerging Markets Finance And Trade, 52 (1), 123135.

Babecky, J., Havranek, T., Mateju, J., Rusnak, M., Smidkova, K., \& Vasicek, B. (2012), Banking, Debt and Currency Crises: Early Warning Indicators, European Central Bank, Working Paper Series, No. 1485.

Barrell, R., Davis, E.P., Karim, D., \& Liadze, I., (2010), Does the Current Account Balance Help to Predict Banking Crises in OECD Countries?, NIESR Discussion Papers, No. 351, National Institute of Economic and Social Research.

Beck, T., A. Demirgüç-Kunt, A., \& Levine, R. (2006), Bank Concentration, Competition and Crises: First Results, Journal of Banking and Finance, 30, 1581-1603.

Boyd, J. H., De Nicolo, G., \& Rodionova, T., (2015), The Determinants of Banking Crises: A Reassessment (July 23, 2015), Available At SSRN: Https://Ssrn.Com/Abstract=2635071 Or Http://Dx.Doi.Org/10.2139/Ssrn.2635 071

Boyd, J., De Nicolo, G., \& Loukoianova, E., (2009), Banking Crises and Crisis Dating: Theory and Evidence, IMF Working Paper, WP/09/141.

Cameron, A., \& Trivedi, P. (2005). Microeconometrics: Methods and Applications. Cambridge: Cambridge University Press. Doi:10.1017/CBO9780511811241

Cergibozan, E., \& Arı, A., (2017) Türkiye'deki Banka Krizlerine Yönelik Ekonometrik Bir Yaklaşım,: Markow Rejim Değişim Modeli, Marmara Üniversitesi İIBF Dergisi, Cilt 39, Sayı 1, 47-64. 
Cihák, M., Demirgüç-Kunt, A., Feyen E. \& Levine, R. (2012), Benchmarking Financial Systems around the World. World Bank Policy Research Working Paper 6175, World Bank, Washington, D.C.

Demirgüç-Kunt, A. \& Detragiache E. (1997), The Determinants of Banking Crises: Evidence from Developing and Developed Countries, IMF Working Paper, WP/97/106.

Demirgüç-Kunt, A., \& Detragiache E. (1998), Financial Liberalization and Financial Fragility, IMF Working Paper, WP/98/83.

Gluzman, P., \& Guzman, M. (2017), Assessing the Robustness of the Relationship between Financial Reforms and Banking Crises, Journal of International Financial Markets, Institutions and Money, 49, Pp. 32-47.

Hamdaoui, M. (2016), Are Systemic Banking Crises in Developed and Developing Countries Predictable?, Journal of Multinational Financial Management, 37-38, 114-138.

Han, R., \& Melecky, M. (2013), Financial Inclusion for Financial Stability: Access to Bank Deposits and Growth of Deposits in the Global Financial Crises, The World Bank Policy Research Working Paper 6577, Background Paper to the 2014 World Development Report.

Hardy, D. C., \& Pazarbaşığlu, C. (1999), Determinants and Leading Indicators of Banking Crises: Further Evidence, IMF Staff Papers, 46 (3).

Jutasompakorn, P., Brooks, R., Brown, C., \& Treepongkaruna, S. (2014), Banking Crises: Identifying Dates and Determinants, Journal of International Financial Markets, Institutions and Money, 32, 150-166.

Kaminsky, G.L., \& Reinhart, C.M. (1999), The Twin Crises: The Causes of Banking and Balance-Of-Payments Problems, The American Economic Review, 89 (3), 473-500.

Koepke, R. (2016), Determinants of Emerging Market Crises: The Role of U.S. Monetary Policy, SSRN Electronic Journal. doi:10.2139/ssrn.2814544

Laina, P., Nyholm, J., \& Sarlin, P. (2015), Leading Indicators of Systemic Banking Crises: Finland in a Panel of EU Countries, Review of Financial Economics, 24, 18-35.

Lang, M., \& Schmidt, P.G. (2016), The Early Warnings of Banking Crises: Interaction of Board Liquidity and Demand Deposits, Journal of International Money and Finance, 61, 129.

Leaven, L., \& Valencia, F. (2008), Systemic Banking Crises: A New Database, IMF Working Papers, WP/08/224. 
Leaven, L., \& Valencia, F. (2013), Systemic Banking Crises Database: An Update, IMF Working Papers, WP/12/163.

Long, J.S., \& Freese, J (2006) Regression Models for Categorical Dependent Variables Using Stata. 2nd Edition, Stata Press, Texas.

Pedro, C.P, Ramalho, J.J.S., \& Da Silva, J.V., (2018), The Main Determinants of Banking Crises in OECD Countries, Review of World Economics, 154, 203-227.

Pena, G., (2016), The Determinants of Banking Crises: Further Evidence, MPRA Paper No. 70093.

Wosser, M. (2015), The Determinants of Systemic Banking Crises: A Regulatory Perspective, National University of Ireland, Department of Economics, Finance and Accounting, Working Paper Series, N265-15. 


\section{EKLER}

EK-1: Bankacılık krizlerinin olasılığını arttıran değişkenlerin özet tablosu

\begin{tabular}{|c|c|c|c|c|c|c|}
\hline Değişken & Orijinal Adı & $\begin{array}{c}\text { Gözlem } \\
\text { Sayısı }\end{array}$ & Ortalama & $\begin{array}{l}\text { Std. } \\
\text { Dev. }\end{array}$ & Min & Max \\
\hline $\begin{array}{l}\text { Bankacılık krizi } \\
\text { kuklası (Bankacılık } \\
\text { krizleri=1, yok=0) }\end{array}$ & $\begin{array}{l}\text { Banking crisis dummy } \\
(1=\text { banking crisis, } \\
0=\text { none })\end{array}$ & 9744 & 0.047 & 0.212 & 0 & 1 \\
\hline $\begin{array}{l}\text { Banka maliyeti gelir } \\
\text { oranı }(\%)\end{array}$ & $\begin{array}{l}\text { Bank cost to income } \\
\text { ratio }(\%)\end{array}$ & 2792 & 58.760 & 19.157 & 3.807 & 218.087 \\
\hline $\begin{array}{l}\text { Banka kredileri banka } \\
\text { mevduatları oranı }(\%)\end{array}$ & $\begin{array}{l}\text { Bank credit to bank } \\
\text { deposits }(\%)\end{array}$ & 7264 & 97.166 & 58.741 & 1.138 & 898.013 \\
\hline $\begin{array}{l}\text { Banka mevduatları } \\
\text { GSYİH oranı }(\%)\end{array}$ & $\begin{array}{l}\text { Bank deposits to GDP } \\
(\%)\end{array}$ & 6223 & 39.761 & 37.301 & 0.186 & 394.597 \\
\hline $\begin{array}{l}\text { Banka borç verme ve } \\
\text { mevduat faiz oranı } \\
\text { farkı }\end{array}$ & $\begin{array}{l}\text { Bank lending-deposit } \\
\text { spread }\end{array}$ & 4039 & 7.918 & 7.435 & 0.025 & 91.758 \\
\hline $\begin{array}{l}\text { Banka faiz dışı } \\
\text { gelirlerinin toplam } \\
\text { gelirlere oranı }\end{array}$ & $\begin{array}{l}\text { Bank noninterest } \\
\text { income to total } \\
\text { income }(\%)\end{array}$ & 2790 & 38.998 & 16.106 & 1.425 & 95.742 \\
\hline $\begin{array}{l}\text { Banka takipteki } \\
\text { kredilerin brüt } \\
\text { kredilere oranı }(\%)\end{array}$ & $\begin{array}{l}\text { Bank nonperforming } \\
\text { loans to gross loans } \\
(\%)\end{array}$ & 1568 & 7.189 & 7.425 & 0.01 & 74.1 \\
\hline $\begin{array}{l}\text { Banka sabit } \\
\text { maliyetlerinin toplam } \\
\text { varliklara oranı }(\%)\end{array}$ & $\begin{array}{l}\text { Bank overhead costs } \\
\text { to total assets }(\%)\end{array}$ & 2611 & 4.115 & 3.511 & 0.010 & 58.774 \\
\hline $\begin{array}{l}\text { Merkez Bankası } \\
\text { varlıklarının } \\
\text { GSYİH'ya oranı (\%) }\end{array}$ & $\begin{array}{l}\text { Central bank assets to } \\
\text { GDP }(\%)\end{array}$ & 5789 & 7.547 & 12.134 & $8.39 \mathrm{e}-07$ & 234.045 \\
\hline $\begin{array}{l}\text { Mevduat bankalarının } \\
\text { varlıklarının } \\
\text { GSYİH'ya oranı (\%) }\end{array}$ & $\begin{array}{l}\text { Deposit money banks' } \\
\text { assets to GDP (\%) }\end{array}$ & 6191 & 44.748 & 39.477 & 0.125 & 349.994 \\
\hline $\begin{array}{l}\text { Özel Sektöre verilen } \\
\text { yurtiçi krediler } \\
\text { (GSYİH'nın \%'si) }\end{array}$ & $\begin{array}{l}\text { Domestic credit to } \\
\text { private sector ( } \% \text { of } \\
\text { GDP) }\end{array}$ & 7009 & 39.070 & 37.644 & 0.198 & 311.063 \\
\hline $\begin{array}{l}\text { Finansal sitem } \\
\text { mevduatlarının } \\
\text { GSYİH'ya oranı }(\%)\end{array}$ & $\begin{array}{l}\text { Financial system } \\
\text { deposits to GDP }(\%)\end{array}$ & 6219 & 40.11679 & 37.32481 & 0.007 & 394.597 \\
\hline GSYİH (cari US\$) & GDP (current US\$) & 8063 & $1.15 \mathrm{e}+11$ & $7.76 \mathrm{e}+11$ & 8824746 & $1.68 \mathrm{e}+13$ \\
\hline $\begin{array}{l}\text { GSYİH (cari US\$) } \\
\text { (logaritma) }\end{array}$ & $\begin{array}{l}\text { GDP (current US\$) } \\
(\operatorname{logarithm)}\end{array}$ & 8063 & 22.752 & 2.513 & 15.993 & 30.451 \\
\hline $\begin{array}{l}\text { Kişi başına GSYİH } \\
\text { (US\$) }\end{array}$ & $\begin{array}{l}\text { GDP per capita } \\
\text { (constant } 2005 \text { US\$) }\end{array}$ & 7768 & 9291.236 & 15543.32 & 50.042 & 158802.5 \\
\hline $\begin{array}{l}\text { Kişi başına GSYİH } \\
\text { (US\$) } \\
\text { (logaritma) }\end{array}$ & $\begin{array}{l}\text { GDP per capita } \\
\text { (constant } 2005 \text { US\$) } \\
(\text { logarithm) }\end{array}$ & 7768 & 7.944 & 1.618 & 3.913 & 11.975 \\
\hline $\begin{array}{l}\text { Gayrisafi Milli Gelir } \\
\text { (US\$) }\end{array}$ & GNI (current US\$) & 7726 & $1.57 \mathrm{e}+11$ & $7.99 e+11$ & $1.27 \mathrm{e}+07$ & $1.70 \mathrm{e}+13$ \\
\hline $\begin{array}{l}\text { Gayrisafi Milli Gelir } \\
\text { (US\$) } \\
(\text { logaritma) }\end{array}$ & $\begin{array}{l}\text { GNI (current US\$) } \\
\text { (logarithm) }\end{array}$ & 7726 & 22.783 & 2.504 & 16.358 & 30.464 \\
\hline $\begin{array}{l}\text { Ödenmemiş toplam } \\
\text { uluslararası } \\
\text { borçlanma }\end{array}$ & $\begin{array}{l}\text { Outstanding total } \\
\text { international debt } \\
\text { securities / GDP }(\%)\end{array}$ & 1632 & 22.328 & 34.771 & 0.030 & 378.651 \\
\hline
\end{tabular}




\begin{tabular}{|c|c|c|c|c|c|c|}
\hline $\begin{array}{l}\text { tahvillerinin } \\
\text { GSYİH'ya oran1 (\%) }\end{array}$ & & & & & & \\
\hline $\begin{array}{l}\text { Hayat sigortası prim } \\
\text { hacminin GSYIH'ya } \\
\text { oran }(\%)\end{array}$ & $\begin{array}{l}\text { Life insurance } \\
\text { premium volume to } \\
\text { GDP }(\%)\end{array}$ & 2971 & 1.406 & 2.128 & 0 & 15.784 \\
\hline $\begin{array}{l}\text { Likit yükümlülükler } \\
\text { (milyon \$) (2000 } \\
\text { sabit fiyatlarla) } \\
\text { (logaritma) }\end{array}$ & $\begin{array}{l}\text { Liquid liabilities in } \\
\text { millions USD ( } 2000 \\
\text { constant) }\end{array}$ & 7238 & 162987.7 & 839749.7 & 12.567 & $1.35 \mathrm{e}+07$ \\
\hline $\begin{array}{l}\text { Likit borçların } \\
\text { GSYİH'ya oranı (\%) }\end{array}$ & $\begin{array}{l}\text { Liquid liabilities to } \\
\text { GDP }(\%)\end{array}$ & 6200 & 47.671 & 38.379 & 0.248 & 399.114 \\
\hline $\begin{array}{l}\text { Bankalar dışı finansal } \\
\text { kurumların } \\
\text { varlıklarının } \\
\text { GSYİH'ya oranı }(\%)\end{array}$ & $\begin{array}{l}\text { Nonbank financial } \\
\text { institutions' assets to } \\
\text { GDP }(\%)\end{array}$ & 1670 & 18.629 & 39.435 & 0.001 & 302.063 \\
\hline $\begin{array}{l}\text { Hayat-dış1 sigorta } \\
\text { primlerinin } \\
\text { GSYIH'ya oranı }(\%)\end{array}$ & $\begin{array}{l}\text { Nonlife insurance } \\
\text { premium volume to } \\
\text { GDP }(\%)\end{array}$ & 3236 & 1.307 & 1.035 & 0.002 & 14.862 \\
\hline $\begin{array}{l}\text { Ödenmemiş } \\
\text { uluslararası özel } \\
\text { borçlanma } \\
\text { senetlerinin } \\
\text { GSYIH'ya oranı (\%) }\end{array}$ & $\begin{array}{l}\text { Outstanding } \\
\text { international private } \\
\text { debt securities to } \\
\text { GDP }(\%)\end{array}$ & 1371 & 18.767 & 35.719 & 0.001 & 363.923 \\
\hline $\begin{array}{l}\text { Ödenmemiş } \\
\text { uluslararası kamu } \\
\text { borçlanma } \\
\text { senetlerinin } \\
\text { GSYIH'ya oranı (\%) }\end{array}$ & $\begin{array}{l}\text { Outstanding } \\
\text { international public } \\
\text { debt securities to } \\
\text { GDP }(\%)\end{array}$ & 1492 & 7.266 & 8.834 & 0.003 & 74.839 \\
\hline $\begin{array}{l}\text { Mevduat bankaları ve } \\
\text { diğer finansal } \\
\text { kurumların özel } \\
\text { kredilerinin } \\
\text { GSYIH'ya oranı (\%) }\end{array}$ & $\begin{array}{l}\text { Private credit by } \\
\text { deposit money banks } \\
\text { and other financial } \\
\text { institutions to GDP } \\
(\%)\end{array}$ & 6216 & 38.941 & 37.343 & 0.010 & 313.851 \\
\hline $\begin{array}{l}\text { Hisse senedi } \\
\text { piyasasında toplam } \\
\text { işlem hacminin } \\
\text { GSYİH'ya oranı (\%) }\end{array}$ & $\begin{array}{l}\text { Stock market total } \\
\text { value traded to GDP } \\
(\%)\end{array}$ & 2082 & 26.744 & 54.107 & 0.001 & 723.588 \\
\hline $\begin{array}{l}\text { Borsa devir hizı oranı } \\
(\%)\end{array}$ & $\begin{array}{l}\text { Stock market } \\
\text { turnover ratio (\%) }\end{array}$ & 2082 & 44.601 & 58.105 & 0.009 & 538.311 \\
\hline $\begin{array}{l}\text { Hisse senedi } \\
\text { fiyatlarının oynaklığ1 }\end{array}$ & Stock price volatility & 1592 & 22.628 & 13.769 & 2.394 & 141.583 \\
\hline $\begin{array}{l}\text { Toplam faktöring } \\
\text { hacminin GSYIH'ya } \\
\text { oranı }\end{array}$ & $\begin{array}{l}\text { Total factoring } \\
\text { volume to GDP (\%) }\end{array}$ & 1168 & 3.050 & 4.055 & 0 & 43.985 \\
\hline
\end{tabular}


EK-2: Bankacılık krizlerinin olasılığını azaltan değişkenlerin özet tablosu

\begin{tabular}{|c|c|c|c|c|c|c|}
\hline Değişken & Orijinal Adı & $\begin{array}{c}\text { Gözlem } \\
\text { Sayısı }\end{array}$ & Ortalama & $\begin{array}{l}\text { Std. } \\
\text { Dev. }\end{array}$ & Min & Max \\
\hline $\begin{array}{l}\text { Bankacıllk } \quad \text { krizi } \\
\text { kuklası } \quad \text { (Bankacılık } \\
\text { krizleri=1, yok=0) }\end{array}$ & $\begin{array}{l}\text { Banking crisis dummy } \\
(1=\text { banking crisis, } \\
0=\text { none })\end{array}$ & 9744 & 0.047 & 0.212 & 0 & 1 \\
\hline $\begin{array}{l}\text { 5-banka varlığı } \\
\text { yoğunlaşması }\end{array}$ & $\begin{array}{l}5 \text {-bank asset } \\
\text { concentration }\end{array}$ & 1898 & 81.624 & 18.072 & 10.612 & 100 \\
\hline $\begin{array}{l}\text { Banka sermayesinin } \\
\text { toplam varlıklara oranı } \\
(\%)\end{array}$ & $\begin{array}{l}\text { Bank capital to total } \\
\text { assets (\%) }\end{array}$ & 1538 & 9.623 & 4.070 & 1.452 & 30.6 \\
\hline $\begin{array}{l}\text { Banka yoğunlaşması } \\
(\%)\end{array}$ & $\begin{array}{l}\text { Bank concentration } \\
(\%)\end{array}$ & 2314 & 74.248 & 21.482 & 7.248 & 100 \\
\hline $\begin{array}{l}\text { Bankanın net faiz } \\
\text { marjini }(\%)\end{array}$ & $\begin{array}{l}\text { Bank net interest } \\
\text { margin }(\%)\end{array}$ & 2594 & 4.921 & 3.210 & 0.032 & 39.237 \\
\hline $\begin{array}{l}\text { Varlıklar üzerinden } \\
\text { banka getirisi (vergi } \\
\text { sonrası, \%) }\end{array}$ & $\begin{array}{l}\text { Bank return on assets } \\
(\%, \text { after tax })\end{array}$ & 2612 & 1.312 & 3.256 & -109.490 & 21.120 \\
\hline $\begin{array}{l}\text { Özsermaye üzerinden } \\
\text { banka getirisi (vergi } \\
\text { sonras1, \%) }\end{array}$ & $\begin{array}{l}\text { Bank return on equity } \\
(\%, \text { after tax })\end{array}$ & 2609 & 13.969 & 18.264 & -294.451 & 242.578 \\
\hline Banka Z-puanı & Bank Z-score & 2600 & 15.294 & 10.639 & -21.224 & 74.130 \\
\hline $\begin{array}{l}\text { Yabancı banka } \\
\text { varlıklarının toplam } \\
\text { banka varlıkları } \\
\text { içindeki payı }(\%)\end{array}$ & $\begin{array}{l}\text { Foreign bank assets } \\
\text { among total bank } \\
\text { assets (\%) }\end{array}$ & 1092 & 43.227 & 32.684 & 0 & 100 \\
\hline Lerner endeksi & Lerner index & 2270 & 0.256 & 0.157 & -1.609 & 1.076 \\
\hline $\begin{array}{l}\text { Likit varlıkların } \\
\text { mevduat ve k1sa vadeli } \\
\text { fonlara oranı }(\%)\end{array}$ & $\begin{array}{l}\text { Liquid assets to } \\
\text { deposits and short } \\
\text { term funding (\%) }\end{array}$ & 2826 & 41.268 & 26.721 & 0.322 & 244.817 \\
\hline $\begin{array}{l}1 \text { milyon kişi başına } \\
\text { listelenen firma sayısı }\end{array}$ & $\begin{array}{l}\text { Number of listed } \\
\text { companies per } \\
1,000,000 \text { people }\end{array}$ & 2396 & 27.590 & 50.472 & 0.012 & 1130.004 \\
\hline $\begin{array}{l}\text { Havale akışının } \\
\text { GSYİH'ya oranı (\%) }\end{array}$ & $\begin{array}{l}\text { Remittance inflows to } \\
\text { GDP }(\%)\end{array}$ & 4913 & 3.930 & 7.897 & 0 & 106.477 \\
\hline $\begin{array}{l}\text { Borsa } \\
\text { kapitalizasyonun } \\
\text { GSYİH'ya oranı (\%) }\end{array}$ & $\begin{array}{l}\text { Stock market } \\
\text { capitalization to GDP } \\
(\%)\end{array}$ & 2110 & 47.549 & 59.707 & 0.012 & 996.939 \\
\hline
\end{tabular}

